\section{The Gastrointestinal Parasites and Bacteria Community of Sable (Mates zibellina) in Northeastern China}

\author{
Danyu Zhang ${ }^{1}$, Ying Liu', Qinxin Shi ${ }^{1}$, Zhiwei Peng ${ }^{1}$, Yan Hua ${ }^{1}$ and Zhijun Hou ${ }^{1,2, *}$ \\ ${ }^{1}$ College of Wildlife Resources, Northeast Forestry University, Hexing Road No. 26, \\ Harbin 150040, P.R. China \\ ${ }^{2}$ Key Laboratory of Wildlife Conservation, China State Forestry Administration, \\ Harbin, P.R. China
}

\begin{abstract}
A B S T R A C T
The sable was one species of holarctic carnivores and it was mainly in Russia, China, and Japan. There have little information about gastrointestinal parasite and bacterium of the sable, but it was important for its health. Five parasitic species and two hundreds thirty four gut bacteria (genus) of the sable were detected by the saturated $\mathrm{NaCl}$ floating and next sequencing methods. The parasites were Capillaria sp., Baylisascaris devosi, Echinochasmus sp., and two Coccidian species. The Echinochasmus sp. and two Coccidian species were first time found either in sable or in other martens. The 434 genus of bacteria, belong to 30 phylum, the more popular bacteria were Proteobacteria (33.54\%), following by Firmicutes (18.58), Acidobacteria (12.82\%), Actinobacteria (9.27\%), Bacteridetes (5.44\%), Crenarchaeota (4.58\%), Fusobacteria (2.66\%), Verrucomicrobia (2.29\%), Gemmatimonadetes $(2.18 \%)$ and Planctomycetes $(1.39 \%)$, and they were more than $92.75 \%$. The gut bacteria of the sable have more diversity than Siberian tiger, panda, horse, and human, and it may originate from the more divertible diet of the sable.
\end{abstract}
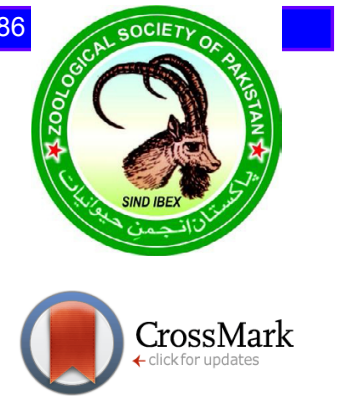

Article Information
Received 07 November 2016
Revised 30 July 2017
Accepted 27 September 2017
Available online 02 August 2018
Authors' Contribution
DZ wrote the article and did lab work.
YL and QS collected the samples
and analysis of data. ZP helped in
morphological observation of the eggs.
YH and ZH designed the study.
Key words
Sable (Mates zibellina), Parasite,
Bacteria community, Northeastern
China.

\section{INTRODUCTION}

$\mathrm{S}_{\mathrm{s}}^{\mathrm{a}}$ able, Martes zibellina (Linnaeus, 1758), one of eight species of Mustela (Mustelidae, Carnivora), is a circumboreal ones (Li, 2012; Steven et al. 1996). Four species of the Mustela, Martes zibellina (sable), Martes americana (American marten), Martes martes (pine marten), and Martes melampus (Japanese marten) are forest-dwelling carnivores that occur allopatrically in coniferous and deciduous forests in the Holarctic region (Ishida et al., 2013). The sables were widespread in all taiga zoogeographical zones of Eurasia, primarily in Russia from the Ural Mountains throughout Siberia, in northern Mongolia and northeastern China, and on Hokkaido in Japan (Malyarchuk et al., 2014; Li, 2012; Zhu et al., 2017).

The sable is generally considered to have the most beautiful and richly tinted pelt among martens. Since the nineteenth century, intensive hunting for pelts has resulted in sable population dramatic declined in Russia and China (Li et al., 2011). Habitat changes associated with forestry utilization had contributed to this loss (Steven et al., 1996). In Russia, sables reached a nadir of distribution and abundance early in this century, but recovered

\footnotetext{
* Corresponding author: houzhijundz@163.com 0030-9923/2018/0005-1681 \$ 9.00/0

Copyright 2018 Zoological Society of Pakistan
}

following protection, development of sable farming, and reintroduction (Steven et al., 1996). To protect the sable, the Chinese government has added it to the list of wildlife under special state protection and has completely prohibited hunting and fur trade for this species since 1988, but the population still has not yet recovered in China until now (Li et al., 2011).

Many studies, especially in the phylogeny, genetic variability and diversity, population genetic structure, species molecular distinguished, and ecology, had been done on the sables (Malyarchuk et al., 2014; Ishida et al., 2013; Mustonen et al., 2006; Zhigileva et al., 2014; Sato et al., 2011; Rozhnov et al., 2010, 2013; Nagai et al., 2012; Monakhov, 2014; Maliarchuk et al., 2010; Li et al., 2014; Kinoshita et al., 2015; Dubinin, 2010). There were also some articles on the parasitism of martens (Table I), but as to our knowledge, this was first report on sable parasitic fauna in China, and there was not any information of gut bacteria community about sable excepting this study.

\section{MATERIALS AND METHODS}

The fresh fecal samples of two rescued sable individuals originated from Northeastern China were collected when they were discharged into the environment timely. The samples was stored frozen at $-20^{\circ} \mathrm{C}$ for using in later. 
Table I.- The parasites community of Marets have been documented.

\begin{tabular}{|c|c|c|c|c|c|}
\hline M. americana & M. martes & M. fonia & M. pennati & M. melampus & M. zibellina \\
\hline Alaria taxideae & 1 & Angiostrongylus sp. & 1 & 1 & 1 \\
\hline Baylisascaris devosi & 1 & Ascaridida & 1 & 1 & Ascaris \\
\hline Crenosoma petrowi & 1 & Capillaria sp. & 1 & 1 & Crenosoma sp. \\
\hline Dioctophyme renale & 1 & Dirofilaria & 1 & 1 & Capillaria $\mathrm{sp}$. \\
\hline Eucoleus aerophilus & 1 & 1 & 1 & 1 & 1 \\
\hline Euryhelmis aquamula & 1 & 1 & 1 & 1 & 1 \\
\hline Filaroides martes & 1 & 1 & 1 & 1 & Filaroides sp. \\
\hline Mesocestoides sp. & 1 & 1 & 1 & Hepatozoon & Mesocestoides sp. \\
\hline Molineus patens & $\begin{array}{l}\text { Skrjabingylus } \\
\text { petrowi }\end{array}$ & $\begin{array}{l}\text { Skrjabingylus } \\
\text { petrowi }\end{array}$ & 1 & 1 & $\begin{array}{l}\text { Skrjabingylus } \\
\text { petrowi }\end{array}$ \\
\hline Pearsonema plica & 1 & 1 & 1 & 1 & 1 \\
\hline Physaloptera sp. & 1 & 1 & 1 & 1 & 1 \\
\hline Soboliphyme baturini & 1 & 1 & Sarcocystis spp. & 1 & Soboliphyme sp. \\
\hline Taenia marits americanan & 1 & Taenia marits & Toxoplasma gondii & 1 & Taenia sp. \\
\hline Taenia mustelae & 1 & Taenia sp. & 1 & 1 & Thominx sp. \\
\hline Trichinella spiralis & Trichinella britovi & Molineus patens & 1 & 1 & 1 \\
\hline $\begin{array}{l}\text { Hoberg et al. (1990), } \\
\text { Zarnke et al. (2004), } \\
\text { Seville and Addison } \\
\text { (1995) and } \\
\text { Poole et al. (1983) }\end{array}$ & $\begin{array}{l}\text { Heddergott et al. } \\
(2015) \text { and Moskwa et } \\
\text { al. (2012) }\end{array}$ & $\begin{array}{l}\text { Heddergott et al. (2015), } \\
\text { Kornas et al. (2013), } \\
\text { Real and Torino (2011) } \\
\text { and Miterpakova et al. } \\
(2013)\end{array}$ & Larkin et al. (2011) & $\begin{array}{l}\text { Kubo et al. } \\
\text { (2009) }\end{array}$ & $\begin{array}{l}\text { Li (2012) and } \\
\text { Heddergott et al. } \\
(2015)\end{array}$ \\
\hline
\end{tabular}

There was no any report in published document.

Subsequently, the parasitic fauna was examined by centrifugal flotation in concentrated $\mathrm{NaCl}$ solutions to detect parasitic eggs as described by Kocijan et al. (2008). The stored examples with dry ice were transformed to Sangon Biotech (Shanghai Co., Ltd.) for detecting the Bacteria fauna. The V3-V4 regions of the bacterial 16S rDNA were amplified and sequenced on the Illunina Miseq platform. The primers were 341F and 805R. 341F: CCCTACACGACGCTCTTCCGATCTG (barcode) CCTACGGGNGGCWGCAG; 805R: GACTGGAGT TCCTTGGCACCCGAGAATTCCAGACTACHVGGGTATCTAATCC) barcodes, chimeras, and out target numbers or ambiguous bases were removed dataset. The remaining Sequences were then clustered into OTUs at a cutoff of $97 \%$ similarity using uclust (v1.1.579). Taxonomic assignments of the OTUs were made down to the genus level (cutoff, 0.8) using the Ribosomal Database Project (RDP) classifier with the Bayesian method.

\section{RESULTS}

Five parasitic species, two nematodes, one trematode, and two protozoa (Coccidian), were found in sable feces, and they are Capillaria sp., Baylisascaris devosi, Echinochasmus sp., and two different Coccidian species (each of them maybe Eimeria sp. or Isospara sp.) (Fig. 1). The Echinochasmus sp. and two Coccidian species were first time found either in sable or in other martens. There were 434 genuses of bacteria, belong to 30 phylums homed in the gut of the sable (Fig. 2, Table I). The more popular bacteria were Proteobacteria (33.54\%), Firmicutes (18.58), Acidobacteria (12.82\%), Actinobacteria (9.27\%), Bacteridetes (5.44\%), Crenarchaeota (4.58\%), Fusobacteria (2.66\%), Verrucomicrobia (2.29\%), Gemmatimonadetes $(2.18 \%)$, and Planctomycetes $(1.39 \%)$, they were more than $92.75 \%$.

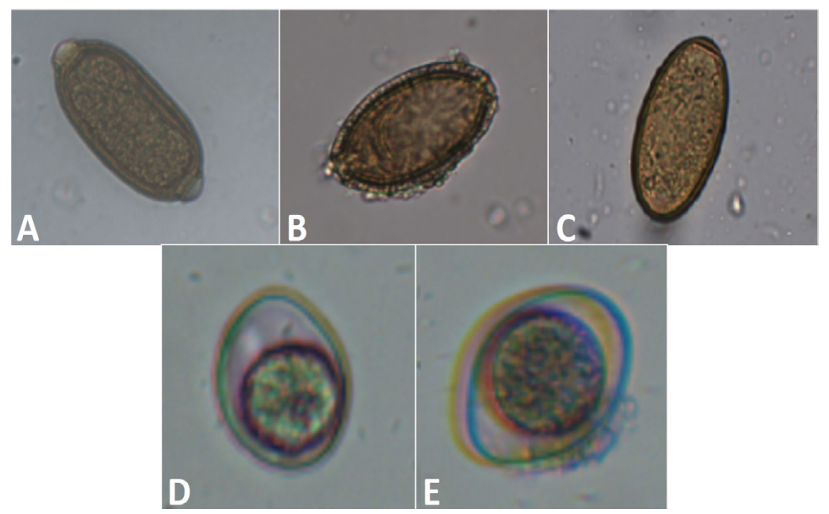

Fig. 1. A, Capillaria sp. $(63.9 \times 25.9 \mu \mathrm{m})$; B, Baylisascaris devosi $(55.6 \times 32.1 \mu \mathrm{m}) ; \quad \mathrm{C}, \quad$ Echinochasmus $\mathrm{sp}$. $(66.9 \times 37.4 \mu \mathrm{m})$; D and E, two different Coccidian species $(31.9 \times 25.9 \mu \mathrm{m})(42.4 \times 31.7 \mu \mathrm{m})$. 


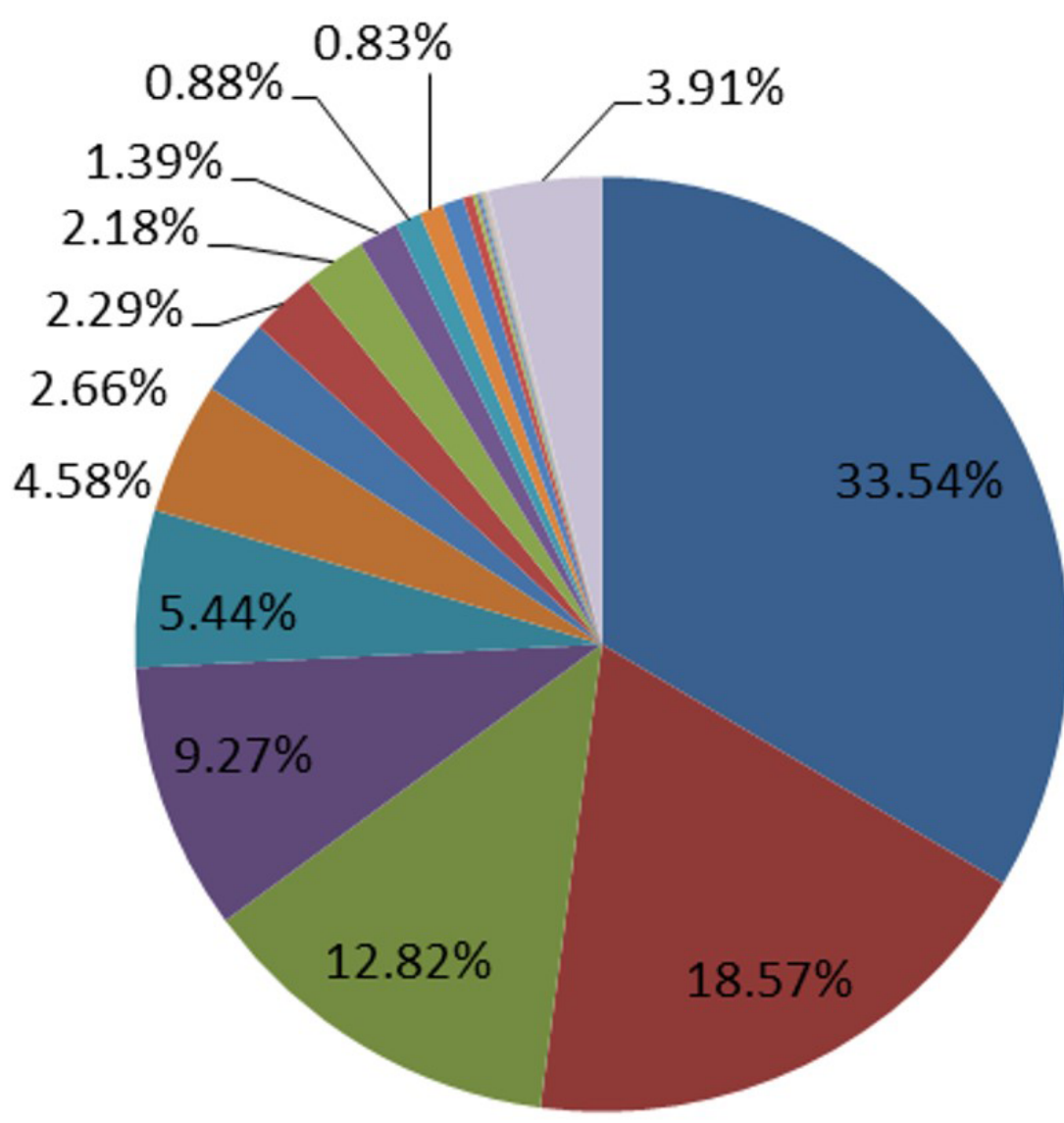

- Proteobacteria $33.54 \%$

- Firmicutes $18.57 \%$

Acidobacteria $12.82 \%$

- Actinobacteria $9.27 \%$

- Bacteroidetes $5.44 \%$

- Crenarchaeota $4.58 \%$

- Fusobacteria $2.66 \%$

- Verrucomicrobia $2.29 \%$

- Gemmatimonadetes $2.18 \%$

- Planctomycetes $1.39 \%$

- TM7 0.88\%

Chloroflexi $0.83 \%$

Euryarchaeota $0.74 \%$

- Nitrospira $0.34 \%$

aD1 $0.14 \%$

- Cyanobacteria/Chloroplast $0.1 \%$

Armatimonadetes $0.08 \%$

- Spirochaetes $0.05 \%$

Synergistetes $0.05 \%$

BRC1 $0.05 \%$

Chlamydiae $0.03 \%$

WS3 0.03\%

Caldiserica $0.01 \%$

Chlorobi $0.01 \%$

Deinococcus-Thermus $0.01 \%$

Elusimicrobia $0.01 \%$

Fibrobacteres $0.01 \%$

unclassified $3.91 \%$

Fig. 2. The bacteria community of the sable gut on phylum.

Table II.- The bacteria communities of the sable, Siberian tiger, panda, horse and human on phylum.

\begin{tabular}{lccccc}
\hline Bacteria groups & Sable & Siberian tiger & Panda & Horse & Human \\
\hline Proteobacteria & $33.54 \%$ & 6.16 & 15.77 & 0.95 & 2.81 \\
Firmicutes & $18.57 \%$ & 33.56 & 83.90 & 69.21 & 57.20 \\
Acidobacteria & $12.82 \%$ & 0 & 0 & Nearby 0 or 0 & Nearby 0 or 0 \\
Actinobacteria & $9.27 \%$ & 2.95 & 0 & 0 & 2.22 \\
Bacteroidetes & $5.44 \%$ & 23.82 & 0.02 & 5.71 & 32.00 \\
Crenarchaeota & $4.58 \%$ & 0 & 0.16 & Nearby 0 or 0 & 0 \\
Fusobacteria & $2.66 \%$ & 33.47 & 0 & 0 & 2.2 \\
Verrucomicrobia & $2.29 \%$ & 0 & 0 & Nearby 0 or 0 & Nearby 0 \\
Gemmatimonadetes & $2.18 \%$ & 0 & 0 & Nearby 0 or 0 & 0 \\
Planctomycetes & $1.39 \%$ & & & 0 \\
\hline
\end{tabular}

\section{DISCUSSION}

Although nine parasitic species had been reported could infect the sable in Russia, only five species were found in this study. Although this may attribute to the zoogeographical zone difference of the sable between in Russia and China, but the limited samples numbers of this study is another cannot be ignored factor. 
The Echinochasmus sp. could infect the sable was discovered in this research at first time. As the document, the rodents, fox, cat, dog, or other some carnivores could be as the final host of the Echinochasmus sp., the river snail as first intermediate host, and fish or frog as the second intermediate host (Kong, 1997). Obviously the Echinochasmus sp. infected the final host when they eaten the frog or fish, which as the second intermediate host. But this situation, it may be not really for sable. Kang et al. (2003) and Xu et al. (1996) had reported that many plants or plant seeds and animals excepting the fish and frog can be as the diet for the sable in China, so if the Echinochasmus sp. was disseminated between sables by fish or frog or by other ways we still unknown was in doubt, and the fact need additional research to do in the future.

Two Coccidian obviously different on the shape (Fig. 1) were detected from the sable feces, but we could not confirmed which specific species they were Isospora, Eimeria, or other coccidian specie, based only on the shape. And egg incubating or molecular way would be a useful method to the fact in next step.

There was three species, Echinochasmus sp., and Eimeria sp. or Isospara sp., were reported either in sables or in other martens at first time, but any other information more that could be afforded in this study, and the potential health risks of those new found parasites for the sable require more additional research.

The sable gut bacteria belong to 26 phylum, contrast with the Siberian tiger, panda, horse, and human, they were $6,6,16$, and 20 one, and it could be concluded that the gut bacteria of the sable had more diversity (Table II). The majority gut bacteria of the sable were Proteobacteria, but other animal ones were Firmicutes. More interesting, the Acidobacteria (12.82\%) were mainly bacteria of the sable, but they were zero or nearby zero in other animals. Those may attribute to the diet diversity of the sable.

Although the data reported in this paper are limited due to relatively small sample size and can therefore be considered preliminary, this study revealed which bacteria and parasites are present in the digestive tract of the sable members. And addressing questions such as the potential health risks for the sable or its role in disease transmission require more exhaustive sampling and additional research.

\section{CONCLUSION}

Five parasitic species and two hundreds thirty four gut bacteria (genus) of the sable were detected.The study concluded that gut bacteria of the sable have more diversity.

\section{ACKNOWLEDGMENT}

This research was supported by the National Key Research and Development Program of China (No. 2018YFD0502201); The Fundamental Research Funds for theCentral Universities(No. 2572018BE07).

\section{Statement of conflict of interest}

There was not any interest conflicts with others person or affiliation, and all authors have seen the manuscript and approved to submit to your journal. This manuscript has neither been submitted nor to be submitted to any other journal.

\section{REFERENCES}

Dubinin, E.A., 2010. On sexual dimorphism in the winter diet of the sable (Martes zibellina L.) Russian J. Ecol., 41: 244-248. https://doi.org/10.1134/ S1067413610030082

Heddergott, M., Muller, F. and Frantz, A.C., 2015. Prevalence and molecular identification of the sinus worm Skrjabingylus petrowi (Nematoda: Metastrongyloidea) from Martes spp. in Germany. Parasitol. Res., 114: 2053-2061. https://doi. org/10.1007/s00436-015-4388-0

Hoberg, E.P., Aubry, K.B. and Brittell, J.D., 1990. Helminth parasitism in martens (Martes americana) and ermines (Mustela erminea) from Washington, with comments on the distribution of Trichinella spiralis. J. Wildl. Dis., 26: 447-452. https://doi. org/10.7589/0090-3558-26.4.447

Ishida, K., Sato, J.J., Kinoshita, G., Hosoda, T., Kryukov, A.P. and Suzuki, H., 2013. Evolutionary history of the sable (Martes zibellina brachyura) on Hokkaido inferred from mitochondrial Cytb and nuclear Mc1r and Tcf25 gene sequences Acta Theriol., 58: 13-24. https://doi.org/10.1007/s13364-012-0103-Z

Kang, B., Ma, J. and Zhang, Y., 2003. Analysis the diet composition of the sable in Daxinanling of China. Acta Theriol. Sin., 23: 203-207.

Kinoshita, G., Sato, J.J., Meschersky, I.G., Pishchulina, S.L., Simakin, L.V., Rozhnov, V.V., Malyarchuk, B.A., Derenko, M.V., Denisova, G.A., Frisman, L.V., Kryukov, A.P., Hosoda, T. and Suzuki, H., 2015. Colonization history of the sable Martes zibellina (Mammalia, Carnivora) on the marginal peninsula and islands of northeastern Eurasia. $J$. Mammal., 96: 172-184. https://oi.org/10.1093/ jmammal/gyu021

Kocijan, I., Prukner-Radovčić, E., Beck, R., Galov, A., Marinculić, A. and Sušić, G., 2008. Microflora and 
internal parasites of the digestive tract of Eurasian griffon vultures (Gyps fulvus) in Croatia. Eur. J. Wildl. Res., 55: 71-74. https://doi.org/10.1007/ s10344-008-0209-4

Kong, F., 1997. Veterinary parasitology, Second edn. The Chinese Agriculture University Publisher, Beijing.

Kornas, S., Wierzbowska, I.A., Gorski, P. and Okarma, H., 2013. Occurrence of internal parasites in stone martens (Martes foina) from Cracow and suburbs. Annls. Parasitol., 59: 203-205.

Kubo, M., Nagataki, M., Agatsuma, T., Sakai, H., Masegi, T., Panciera, R.J. and Yanai, T., 2009. Parasitological and molecular features of the Hepatozoon species in the myocardium of Japanese Martens (Martes melampus melampus). J. Parasitol., 95: 1496-1502. https://doi.org/10.1645/ GE-2187.1

Larkin, J.L., Gabriel, M., Gerhold, R.W., Yabsley, M.J., Wester, J.C., Humphreys, J.G., Beckstead, R. and Dubey, J.P., 2011. Prevalence to Toxoplasma gondii and Sarcocystis spp. in a reintroduced fisher (Martes pennanti) population in Pennsylvania. $J$. Parasitol., 97: 425-429. https://doi.org/10.1645/ GE-2623.1

Li, B., 2012. Sables: Their biology, husbandry and ulilization. The Chinese Forestry Publisher, Beijing.

Li, B., Xu, Y.C., Ma, Y., Elmeros, M., Lan, T.M. and Bai, S.Y., 2011. A PCR-RFLP-based method to distinguish sable (Martes zibellina) and pine marten (Martes martes). Acta Theriol., 56: 283288. https://doi.org/10.1007/s13364-011-0027-z

Li, M., Xia, W., Wang, M., Yang, M., Zhang, L. and Guo, J., 2014. Application of molecular genetics method for differentiating Martes zibellina L. heart from its adulterants in traditional Chinese medicine based on mitochondrial cytochrome $\mathrm{b}$ gene. Mitochondrial DNA, 25: 78-82. https://doi.or g/10.3109/19401736.2013.815167

Maliarchuk, B.A., Petrovskaia, A.V. and Derenko, M.V., 2010. Intraspecific structure of sable Martes zibellina inferred from nucleotide variation of the mitochondrial DNA cytochrome $b$ gene. Genetika, 46: 73-78. https://doi.org/10.1134/ S1022795410010102

Malyarchuk, B., Derenko, M. and Denisova, G., 2014. A mitogenomic phylogeny and genetic history of sable (Martes zibellina). Gene, 550: 56-67. https:// doi.org/10.1016/j.gene.2014.08.015

Miterpakova, M., Hurnikova, Z., Zalesny, G. and
Chovancova, B., 2013. Molecular evidence for the presence of Dirofilaria repens in beech marten (Martes foina) from Slovakia. Vet. Parasitol., 196: 544-546. https://doi.org/10.1016/j. vetpar.2013.02.028

Monakhov, V.G., 2014. Size structure of the sable in the Lake Baikal Region: A decadal analysis over the last sixty years. Izvestiia Akademii Nauk Seriia Biologicheskaia, Rossiiskaia Akademiia Nauk, pp. 40-47.

Moskwa, B., Gozdzik, K., Bien, J., Bogdaszewski, M. and Cabaj, W., 2012. Molecular identification of Trichinella britovi in martens (Martes martes) and badgers (Meles meles); new host records in Poland. Acta Parasitol., 57: 402-405. https://doi. org/10.2478/s11686-012-0054-1

Mustonen, A.M., Puukka, M., Saarela, S., Paakkonen, T., Aho, J. and Nieminen, P., 2006. Adaptations to fasting in a terrestrial mustelid, the sable (Martes zibellina). Comp. Biochem. Physiol. Part A: Mol. Integrat. Physiol., 144: 444-450. https://doi. org/10.1016/j.cbpa.2006.03.008

Nagai, T., Murakami, T. and Masuda, R., 2012. Genetic variation and population structure of the sable Martes zibellina on eastern Hokkaido, Japan, revealed by microsatellite analysis. Mamm. Stud., 37: 323-330. https://doi.org/10.3106/041.037.0406

Poole, B.C., Chadee, K. and Dick, T.A., 1983. Helminth parasites of pine marten, Martes americana (Turton) from Ontario, Canada. J. Wildl. Dis., 19: 10-13. https://doi.org/10.7589/0090-3558-19.1.10

Real, J.M.C. and Torino, E.F., 2011. Helminth parasites in stone martens (Martes foina) from Italy. Zeitschrift fur Jagdwissenschaft, 47: 229-231.

Rozhnov, V.V., Meschersky, I.G., Pishchulina, S.L. and Simakin, L.V., 2010. Genetic analysis of sable (Martes zibellina) and pine marten (M. martes) populations in sympatric part of distribution area in the northern Urals. Russian J. Genet., 46:488-492. https://doi.org/10.1134/S1022795410040150

Rozhnov, V.V., Pishchulina, S.L., Meshcherskii, I.G., Simakin, L.V., Lazebnyi, O.E. and Kashtanov, S.N., 2013. Genetic structure of sable (Martes zibellina L.) from Eurasia based on distribution of mitochondrial lineages. Genetika, 49: 251-258.

Sato, J.J., Hosoda, T., Kryukov, A.P., Kartavtseva, I.V. and Suzuki, H., 2011. Genetic diversity of the sable (Mantes zibellina, Mustelidae) in Russian far east and Hokkaido inferred from mitochondrial NADH dehydrogenase subunit 2 
gene sequences. Mamm Stud., 36: 209-222. https:// doi.org/10.3106/041.036.0404

Seville, R.S. and Addison, E.M., 1995. Nongastrointenstinal helminths in marten (Mates americnana) from Ontario, Canada. J. Wildl. Dis., 31: 529-535. https://doi.org/10.7589/0090-355831.4.529

Steven, W.B., Ma, Y., Xu, L. and Jiang, Z., 1996. Winter habitat ecology of sables (Martes zibellina) in relation to forest management in China. Ecol. Appl., 6: 318-325. https://doi.org/10.2307/2269575

Xu, L., Jiang, Z., Ma, Y., Jin, A. and Wang, Y., 1996. Analusis of the winter diet of the sable in China. Acta Theriol. Sin., 16: 272-277.

Zarnke, R.L., Whitman, J.S., Flynn, R.W. and ver Hoef, J.M., 2004. Prevalence of Soboliphyme baturini in marten (Martes americana) populations from three regions of Alaska, 1990-1998. J. Wildl. Dis., 40: 452-455. https://doi.org/10.7589/0090-355840.3.452

Zhigileva, O.N., Politov, D.V., Golovacheva, I.M. and Petrovicheva, S.V., 2014. Genetic variability of sable Martes zibellina L., pine marten M. martes L., and their hybrids in Western Siberia: Protein and DNA polymorphism. Genetika, 50: 581-590. https://doi.org/10.1134/S1022795414050135

Zhu, W.C., Wei, Q.G., Xue, S.Y., Zhang, H.X., Lv, T.S. and Zhang, H.H., 2017. Isolation and characterization of microsatellite markers for the sable, Martes zibellina (Mammalia: Mustelidae) Pakistan J. Zool., 49:1909-1912 http://dx.doi. org/10.17582/journal.pjz/2017.49.5.sc1 